\title{
Comparative Study of Heavy Metals in Soil and Ground Water of Various Areas
}

\author{
Varsha Rani Jain ${ }^{1}$, Dr. Aaparna Gandhe ${ }^{2}$ \\ ${ }^{1,2}$ Department of Chemistry, Holkar Science College Indore, India
}

\begin{abstract}
The heavy metal present in soil and ground water enters into food chain and causes serious health issues. Heavy metals are not biodegradable thus it causes serious environmental problem. The present study was carried out with samples of soil and ground water from some commercial and industrial areas of Indore (Polo ground, Indian oil corporation AB road, Holkar Science College, Poultry form sanwer road, Cement Roofing industry AB road Manglia Indore, Greater Vaishali, Pond in front of Shanchi milk industry ) and then the results of both water and soil ware compared. To determine the concentration of heavy metal in soil and water AAS (Atomic Absorption spectroscopy) is used. Before determine the concentration of some heavy metal we first analyzed some physicochemical properties and finally the study concluded that pretreatment process for reducing the amount of heavy metal is mandatory before the soil can be used as soil conditioner or fertilizer in the soil.
\end{abstract}

Keywords: Heavy metal, Contamination, $\mathrm{pH}$, Conductivity, Pollution, AAS

\section{Introduction}

It is well known fact that in our ecosystem heavy metals are present naturally. In current scenario some of the heavy metals are introduce in the eco-system from anthropogenic sources i.e. pollution from/human activities through direct ingestion or contact with contaminated soil to the food chain (soil-plant-human or soil-plant-animal-human). Polluted water and soil sources may become dangerous for health causing various cancers cardiovascular or neurological diseases. For instance lead in human body causes Anemia, nephropathy (kidney disease), Encephalopathy (brain dysfunction). Chromium in human body leads to pulmonary fibrosis (Lung scarring), lung cancer, hemolysis. Cadmium causes osteomalacia (Softing of bones), proteinuria (excess protein in urine)

"The united states of environmental protection agency (US EPA) sets the levels of metals in soil and water called soil screening level (SSL)". The acceptable limit according to WHO 2008 for heavy metal in $\mathrm{mg} / \mathrm{kg}[2,5]$ is given in below table I

Table 1: Acceptable limit for heavy metal in $\mathrm{mg} / \mathrm{kg}$

\begin{tabular}{|c|c|c|c|c|c|c|c|}
\hline $\mathrm{Fe}$ & $\mathrm{Ni}$ & $\mathrm{Pb}$ & $\mathrm{Zn}$ & $\mathrm{Cr}$ & $\mathrm{Cu}$ & $\mathrm{Cd}$ & $\mathrm{Mn}$ \\
\hline 0.30 & 0.10 & 0.05 & 5.0 & 0.05 & 1.0 & 0.005 & 0.10 \\
\hline
\end{tabular}

In this research work sample of soil and ground water is taken from different industrial and commercial areas of Indore and then the sample were tested using AAS method. The results of soil and water are compared.

\section{Literature Review}

Mehari Murz Weldemariam use AAS method to determine concentration of heavy metal (cd, cr, fe, cu, zn, pb) in sludge sample from apex weaving and finishing mills in almeda textile industry northern tigrai, Ethipia.[1] The study concluded that pretreatment process for reducing the amount of heavy metal is mandatory before the sludge can be used as a soil conditioner or fertilizer in the agricultural soil.

Chaitali V. Mohod Jayashree Dhote collected sample of water from various sources at ground surface and tap water this sample were tested by Atomic Absorption Spectroscopy and differential pulse anodic stripping voltammetry (DPASV). The determination of heavy metals found in their respected work were as $\mathrm{Cd}, \mathrm{Cr}, \mathrm{Co}, \mathrm{Fe}, \mathrm{Mn}, \mathrm{Pb}, \mathrm{Ni}, \mathrm{Zn}$ the concentration determine were more than the maximum admissible and desirable limit when compared with the national and international organization like WHO (2008), USEPA,EUC ,EPA.

Opaiuwa, O.D., Aremu, M.O., Ogbo, L.O., Abiola, K.A., Odiba, I.E., Abubakar, M.M., and Nweza, N.O. studied on heavy metal concentration in soils, plant leaves and crops grown around dump sites in Lafia Metropolis Nasarawa State Nigeria by Atomic Absorption spectroscopy. They found that The values of all the metals analyzed for samples from dumpsites were higher than those from the control site suggesting possible mobility of metals from dumpsites to farmlands through leaching and runoffs, but were below values recommended by the World Health Organization (WHO)

\section{Material and Methods}

The soil and water were collected from different commercial and industrial areas of Indore city, in rainy season july 2015,

To take the sample the whole field is divided into 4 equal sector, from each sector the soil sample were collected from 2 layers i,e. upper layer (1c.m.-2 c.m.) and lower layer (6 c.m.-7 c.m.) and the temperature was noted immediately. Sample taken from each sector were mixed in equal proportion to get the final sample.

Water sample were collected directly from the reservoir without any prior processes. The soil composites were store 


\section{International Journal of Science and Research (IJSR) \\ ISSN (Online): 2319-7064}

Index Copernicus Value (2013): 6.14 | Impact Factor (2015): 6.391

in air tight polythene bags water sample store in plastic bottles and keep in cool place and there both were labeled.

We used AAS for analysis of heavy metals in soil and water, because of high accuracy of AAS. The result will be in ppm and ppb. The reason behind using AAS is that it can detect the target metal in present of many metals.

\section{Result and Conclusion}

The table below shows the results. It can be seen from the table II that the concentration of heavy metal in water is negligible as compared to soil of respective area.

Table 2: Observed heavy metal in $\mathrm{mg} / \mathrm{kg}$ in Sample

\begin{tabular}{|c|c|c|c|c|c|c|c|c|c|c|c|c|c|c|c|c|}
\hline \multirow{2}{*}{$\begin{array}{c}\text { Metal } \\
\text { Location }\end{array}$} & \multicolumn{2}{|c|}{ Iron } & \multicolumn{2}{|c|}{ Cromium } & \multicolumn{2}{|c|}{ Nickel } & \multicolumn{2}{|c|}{ Cupper } & \multicolumn{2}{|c|}{ Zink } & \multicolumn{2}{|c|}{ Lead } & \multicolumn{2}{|c|}{ Manganese } & \multicolumn{2}{|c|}{ Cadmium } \\
\hline & Soil & Water & Soil & Water & Soil & Water & Soil & Water & Soil & Water & Soil & Water & Soil & Water & Soil & Water \\
\hline $\begin{array}{l}\text { Pologround near Police } \\
\text { petrol pump }\end{array}$ & 5.100 & NIL & 0.707 & NIL & 0.416 & NIL & 0.432 & NIL & 0.686 & 0.006 & 0.589 & NIL & 2.6 & NIL & NIL & NIL \\
\hline $\begin{array}{c}\text { AB Road Manglia } \\
\text { Cement Roofing } \\
\text { Industry }\end{array}$ & 3.450 & NIL & 0.472 & NIL & 0.298 & NIL & 0.495 & NIL & 1.320 & NIL & 2.231 & NIL & 1.9 & NIL & NIL & NIL \\
\hline $\begin{array}{c}\text { AB Road Manglia Indian } \\
\text { Oil Corporation }\end{array}$ & 3.558 & 0.498 & 1.587 & NIL & .0597 & NIL & 0.264 & NIL & 0.630 & 0.064 & 0.234 & 0.028 & 2.5 & 1.206 & NIL & NIL \\
\hline $\begin{array}{c}\text { AB Road Manglia Pond } \\
\text { in front of Sanchi Milk } \\
\text { Industry }\end{array}$ & 4.527 & 0.049 & 0.745 & NIL & 0.669 & NIL & 0.293 & NIL & 0.426 & NIL & 0.170 & NIL & 3.47 & 0.245 & NIL & NIL \\
\hline $\begin{array}{c}\text { Sanwer road Poultry } \\
\text { farm }\end{array}$ & 3.830 & NIL & 0.395 & NIL & 0.399 & NIL & 0.631 & NIL & 1.630 & 0.002 & 5.526 & 0.380 & 2.5 & NIL & NIL & NIL \\
\hline Holker science Collage & 0.530 & NIL & 0.093 & NIL & 0.592 & NIL & 0.160 & NIL & 0.235 & 0.020 & 0.309 & NIL & 2.6 & NIL & NIL & NIL \\
\hline Greater Vaishali & 5.102 & 0.051 & 0.505 & NIL & 0.443 & NIL & 0.378 & NIL & 0.359 & 0.022 & 0.125 & NIL & 2.9 & NIL & NIL & NIL \\
\hline
\end{tabular}

The results were also compared with permissible limits of heavy metal in water and soil standardized by international organization $\mathrm{WHO}$ and it was found that the concentration of $\mathrm{Fe}, \mathrm{Ni}, \mathrm{Pb}, \mathrm{Cr}, \mathrm{Mn}$. metal are exceeding permissible limit in all locations and concentration of heavy metal in water is under limit except iron in water of oil industry

\section{References}

[1] Mehari Muuz Weldemariam "Heavy Metal ( $\mathrm{Pb}, \mathrm{Cd}, \mathrm{Zn}$, $\mathrm{Cu}, \mathrm{Cr}$ and $\mathrm{Fe}$ ) Content in Almeda Textile Industry Sludge, Northern Tigrai" in International Journal of Scientific and Research Publications, Volume 4, Issue 1, January 2014.

[2] Chaitali V. Mohod , Jayashree Dhote" Review of heavy metals in drinking water and their effect on human health" in International Journal of Innovative Research in Science, Engineering and Technology Vol. 2, Issue 7, July 2013'

[3] Opaluwa, o. d., aremu, m. o., ogbo, 1. o, abiola, k. a., odiba, i. e., abubakar, m. m. and nweze, n.od "Heavy metal concentrations in soils, plant leaves and crops grown around dump sites in lafia metropolis, nasarawa state, Nigeria" in pelagia research library in advances in applied science research, 2012, 3 (2):780-784.

[4] Siddique na, mujeeb m, "Determination of Heavy Metal in Medicinal Plants by Atomic Absorption Spectroscopy (AAS)" in International Journal of Phytotherapy Research, issn 2278 - 5701, volume 3, issue 42013.

[5] D. F. Adewumi, I. A. Daniyan, A. O. Adeodu, "Determination of Heavy Metals in Water, Fish and Soil Samples from Antau River in Keffi, Nasarawa State, Nigeria: A Case Study of Antau River in Keffi, Nasarawa North Central Nigeria" in International Journal of Science and Research (IJSR) ISSN (Online): 2319-7064, Volume 3 Issue 3, March 2014.

[6] W. J. S. Mwegoha* and C. Kihampa, "Heavy metal contamination in agricultural soils and water in Dar es Salaam city, Tanzania" in African Journal of Environmental Science and Technology Vol. 4(11), pp. 763-769, November, 2010 